\title{
雇い実工法によるカーテンウォール外壁材料の取り付け金具 に関する考察 \\ THINKING ON HARDWARE OF FIXING CURTAIN WALL WITH SPLINE JOINT
}

鈴木 要*

Kaname SUZUKI

\begin{abstract}
Spline joint has been usually fixed with nailing on the frame of structure. So it is impossible to release from the diformation of the structural frame. In this report,wall panel with a spline joint mechanism has become to have a curtain wall mechanism with introducing peculiar hardware.Especially that has discussed from the structural and the extent of accomplishment point of view.
\end{abstract}

Keywords:curtain wall, hardened cement paste, fixed point, slide point, spline joint

カーテンウォール, セメント硬化体, 固定点, スライド固定点, 雇い実

\section{1.はしめめに}

材料の取り付け工法としての雇い実工法は、雇を造り出す本実工 法と異なり、接合する双方の部材に满をしゃくり、满に他の部品を 実として填め込み、双方の部材を接き合わせる工法であり、建造物 の各所に使用される工法である。その特徵としては、小さな部材を 組み合わせにより大きな部材として構成可能とする点にある。しか し、固定方法は、特に木質系においては、釘により確実に下地に固 定することに主眼が固かれ、現況の固定方法では、下地の変形（構 造体の層間変位など）を吸収することは困難といえる。

一方、高層建築の外壁に使用されることの多い、カーテンウォー ルエ法は" ${ }^{1}$ 、金属系、プラスチック系、コンクリート系などの材料 により構成されることが多く、構造的には、躯体部分の柱、梁と外 壁パネルは一体化されておらず、スライド、ロッキング、面内撓み などにより躯体の変形を吸収する構造がとられている。

ところで、建設現場の至る所で建築材料として使用されることの 多いコンパネは、製造方法の技術的進歩により大量生産が可能とな ったが、同時に、供給過剩による、コンパネの価格低迷現象を生じ た。そこで、コンパネをセメントモルタルと複合化し、木質下地の 外壁材として工場生産できたならば、木造下地への取り付が容易で
ある、施工工程が簡略化される、工場生産であるため、現場施エと 異なり、外壁材として確実な強度のセメントモルタルが得られるな どの有用性が期待できる。また、コンパネの価格相場に関係なく、 外壁材を構成する部材の一部としての需要が生じるため、コンパネ に付加価値を付けるなどの経済的効果の生じることも期待される。 このような期待を含めて、本報告は、木質下地のセメント系カーテ ンウオールで、㕍い実工法でもある、外壁材の躯体への固定方法に 関する考察を行うものである。具体的には、雇い実工法による、外 壁材料の、取り付けに使用する金具の考案が、カーテンウオールエ 法として完成していく経過において重要なポイントであることを、 構造学的視点と工法的完成度の視点から考察するものである。

\section{2. 対象外壁材の概要と問題提起}

外壁材料の構成概要を図一 1 に模式図により示す ${ }^{2)}$ 。表面はセメ ントモルタル、木質骨格を持ち、防水兼断熱首をメタルラスにより 包み、構造用合板（コンパネ）にステーブル打ちをすることにより 固定されている。製品の寸法のモジュールは、300 mm、450 mm、 $600 \mathrm{~mm} 、 900 \mathrm{~mm}$ が用意され、製品厚さは $50 \mathrm{~mm}$ 、重量は約 40 $\mathrm{K} g / \mathrm{m}$ であり、取り付けは、コンパネで構成される骨格部分を、 
木䆩の間柱に釷で固定し、扈い実をしゃくり部分に詰め込み、次の 部材を接き合わせ、固定する㕍い実工法が用いられている。一個の 部苻の寸法が、構造的に下地の変形の影竪を受けないほど小さい場 合、或いは、取り付け下地の変形が無視できるほど小さい場合、釘 による下地への固定でも問題は生じないが、外壁面で、外力による 下地の変形 (層間変位) の大きい場合や材料の寸法が大きい場合、 長期にわたる繰り返し变形による、固定箇所の破損など、構造的な 問題を生じか私ない。従って、權造的な問題点の解決という視点で、 また、取り付けエ法の完成度という視点においても、取り付けエ法 の考案が待たれる状況にあった。

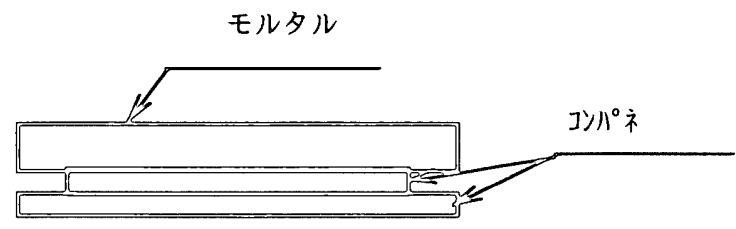

立 面 図

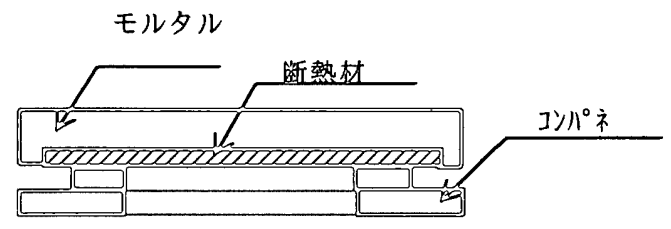

断面図

図- 1 考察対鰁材料構成

\section{3。职り付け工法の昸逐}

3.1 釷による取り付け点の固定

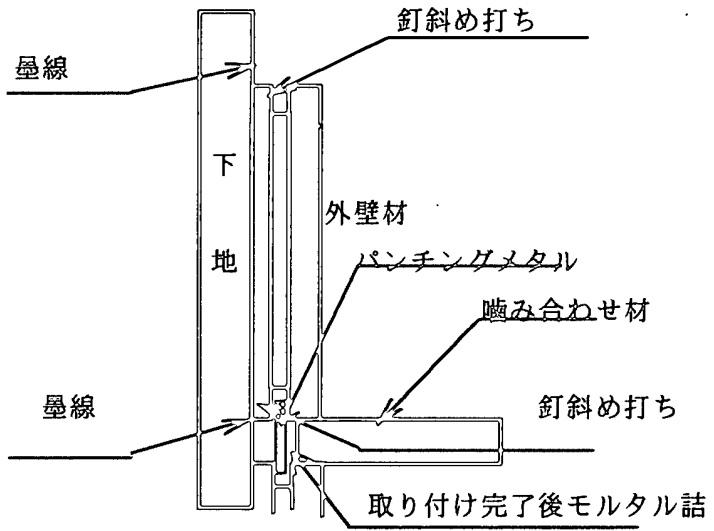

図一 2 取り付け方法 1 （断面）

\section{(1)工法概要}

図ー2に示すように、下地は不質の間柱、雇の材質はパンチング

メタル、目地は防水モルタルを詰めることにより防火槽造とするこ とが可能である。材料モジュールは $300 \mathrm{~mm}$ とし、外壁面に $300 \mathrm{~mm} \times 90$ 0mmのグリッドの目地を入れ、同時に、15mmの目地による壁面デザイ ンを配虑した。取り付け前、下地に量線を入れ、墨線に合わせて、 図ー 3 に示すように、 4 点、或いは 6 点を斜め釘打ちにより固定し た。次に、決り部分に、雇を詰め込み、図一 2 に示すように、目地 湢に等しい寸法の角材を小口部分に配置した後、次の材料を固定箇 所に設定、同様に釘の斜め打ちにより固定し、さらに釗締により内 部に樑く打ち込んだ。

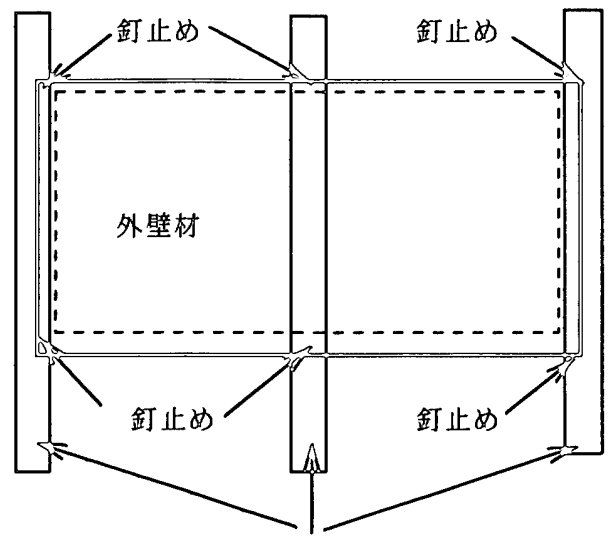

下地（間柱）

図-3 取り付け方法 1（固定方法）

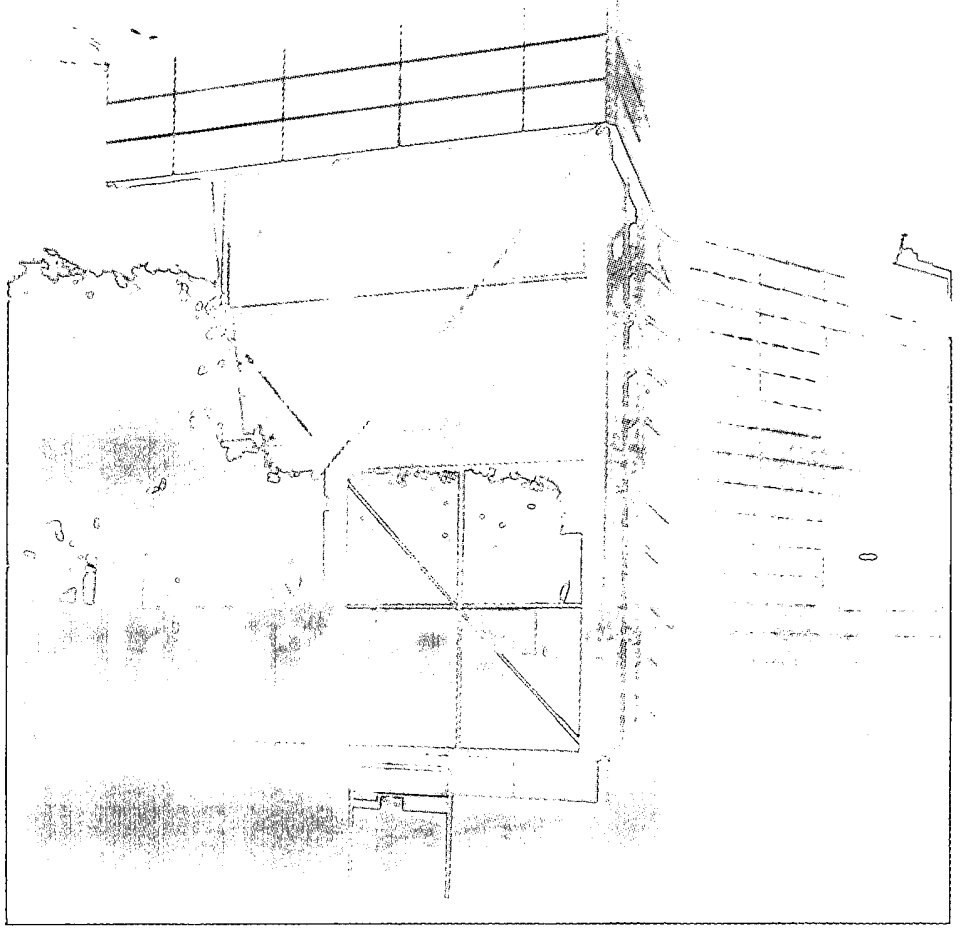

写真－1 横長による施工例（田丸邸，建築知識1978.3） （吉田研介車海大学教授設計及び撮影）

(2)粠造的問題点

この、固定方法の場合、固定箇所の 4 点或いは 6 点が固定され、 
壁面の層間変位の吸収は不可能であり、従来の雇い実工法と何等変 わり無いことになる。即ち、製品寸法が比較的小さく、壁面の層間 変位の小さい場合にのみ長期の変形に耐えるにすきない。従って、 図ー3,写真一 1 のように、製品を縦長ではなく横長に取り付けなけ ればならない制限が生じる。

(3)工法完成度

釘斜め打ち、釘締めによる締め付け、噛み合わせの木片を使用す るなど、取り付けエ法は、従来の雇い実取り付け工法の域を脱して いないものといえる。

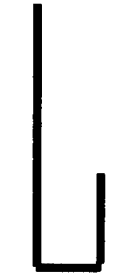

断面図

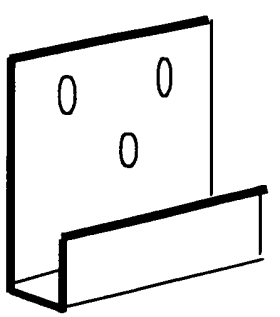

見取り図

図-5 L 形の取付金具

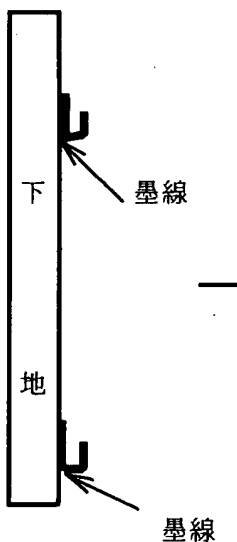

金具取付

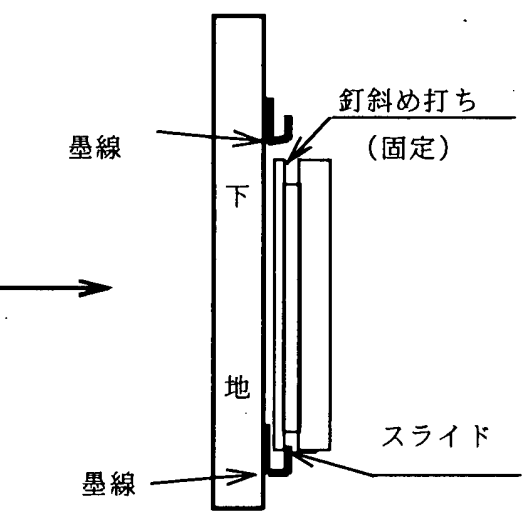

材料固定

図ー6 L 金具による取り付けエ程

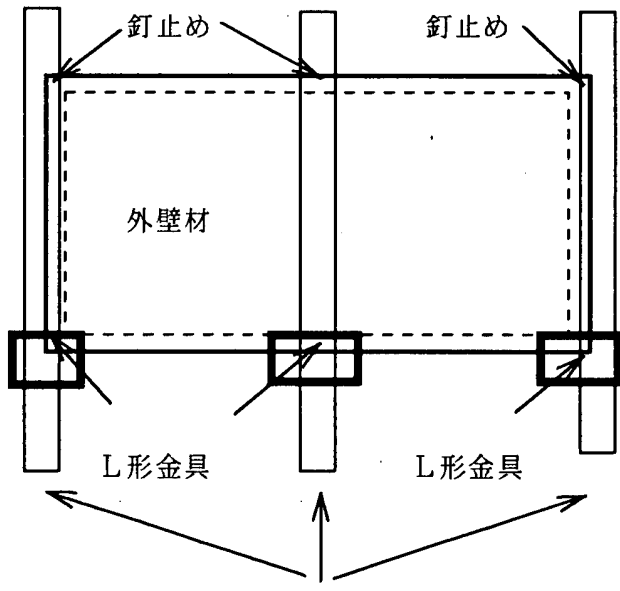

下地（間柱）

図-7 L 形金具を使用しての工法
3.2 L形金具による取り付け

(1)工法概要

図ー5に示す形状の、平面に3 力所の釘穴をあけたL形垔鉛処理 鉄板の金具を作成、図一 6 に示すように、製品下端の畦線に沿って、 釘により下地の間柱に固定、金具にコンクリートパネル部分の下端 を乗せ、上端 2 点あるいは 6 点を釗により固定するエ法とした。

\section{(2)構造的問題}

この手法による固定の場合、図一 7 に示すように、下端の 2 或い は 3 点は、変形に対してスライドすることにより層間変位を吸収す ることになり、上端 2 或いは 3 点が下地に釘で固定され、カーテン ウォールのシステムが構成される。しかし、釘の斜め打ちで固定す る場合、強度に関する不安が残り、適当な金具による固定が望まれ る。

\section{(3)工法完成度}

上端を釘で固定する釘の斜め打ち工法は、L形金具の使用により、 添え木を用いる必要は無いにしても、製品の完成度の視点からする と、高い評価のできるものとはいえない。専用金具による取り付け システムの完成が待たれる状況といえる。

3.3 L形金具と複数の金具の組み合わせによる取付

\section{(1)工法概要}

釘止めを、金具に変えて取り付けるため、下端は図ー 7 のL形金

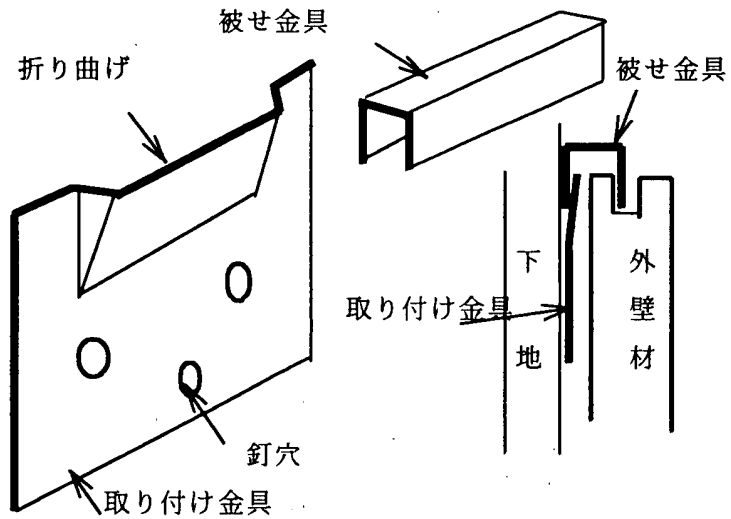

図 -8 上端固定組合せ金物

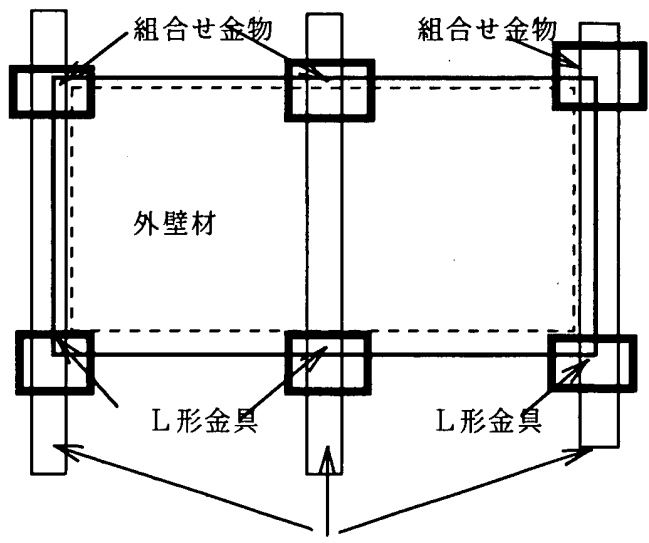

下地（間柱）

図ー9 3 種類の金具によるカーテンウォール 
具を用い、上端固定部を図ー8のような金具で取り付ける、組み合 わせエ法を試みた。

\section{(2)構造的問題}

図ー9に示すように、専用金具による上端固定、下端スライドの カーテンウォールエ法が完成する。しかし、水平方向の変位である 層間変位には対応できるが、上下動に対しては、下地に固定されて いないことになり、地震時落下するなどの構造的問題を残す。 (3)工法完成度

上端固定金具は 2 種頑の組み合わせによる取り付けとなり、L形 金具が下端に取り付けられ、合計 3 種穎の金具を必要とすることに なり、製品完成度としてはいまひとつの感が拭えない。1 種穎の金 具により上端固定、下端スライドのカーテンウォールエ法の完成が 望まれる。

\section{4 特殊金具の開発}

(1)工法概要

一個の金具によるカーテンウオール材の取り付けは、製品の完成 度の視点からも、また、市場性の視点からしても求められるもので ある。取り付け順序を図ー11に示す。下端金具は下地に先付けし、 上端金具は、外壁材の雇いの決りの部分に釘の襄打ちにより予め取 り付ける。次に、下端の金具に虽い実の決り部分を乗せ、上端金具 を表から下地に取り付ける。

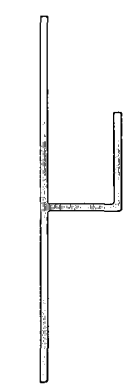

断面図

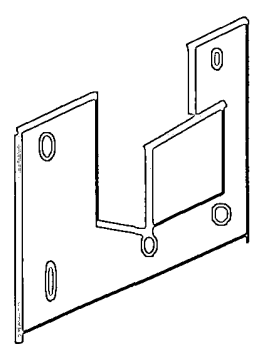

見取り図
図 -10 特殊金具
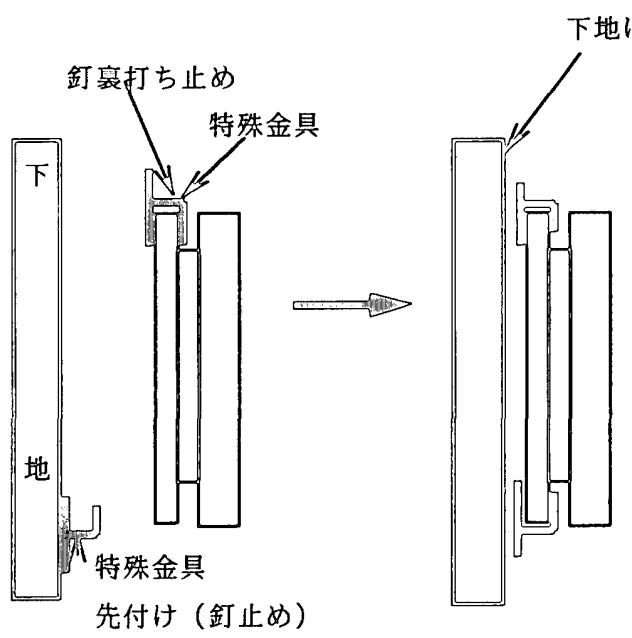

図-11 取り付け
水平方向の層間変位にも上下動にも対応可能な取り付け工法が完 成したものといえる。また、1 種頑の金具により、全ての固定が可 能となる。しかし、理翖的考察にすぎす、カーテンウォールエ法の システムとしての作動状況に関する実験的検討及び施工例での検証 が待たれる。

(3)工法完成度

図ー10に示す金具を取り付け金具として採用した場合、1 種類の 金具により、上端固定、下端スライドのカーテンウォールエ法が完 成する。槽造的問題が解決し、部品数が最少の視点からすると完成 度が高いと判断される。

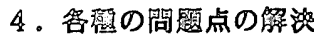

カーテンウォールエ法の外壁材として完成させるためには、金具 の開発以外のクリヤーしなければならない各種の問題点が存在した。 以下にそのポイントを示す。

(1)セメントモルタルのひび割れ破壊問題 ${ }^{4) ~ \sim 8) ~}$

材料構成の視点からすると、骨格のコンクリートパネルと表面の モルタルの乾燥収縮による長さ変化の差は、材料寸法が小さい場合、 殆ど無視しても問題は生じない。しかし、材料寸法が大型化した場 合、或いは、モルタルの強度が小さい場合、拘束されたセメント硬 化物のひび割れ破壊が生じ、現場によっては、ひび割れによる污れ

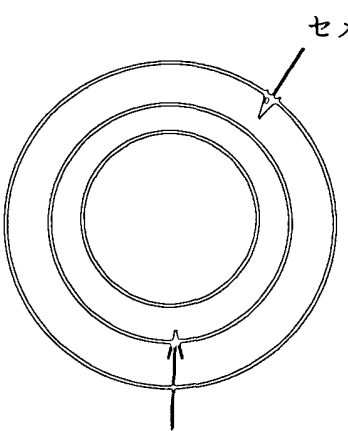

鋼製リング

(拘束体)

理論解析用供試体

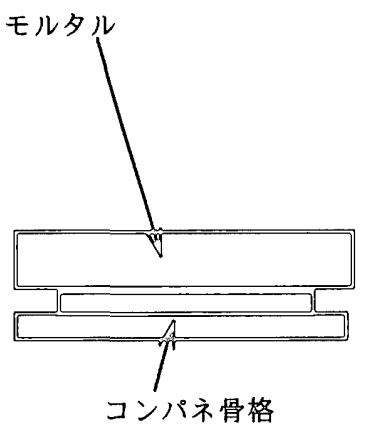

（拘束体）
セメント系複合建篡材料

図-12 破壊解析用供試体と複合建築材料の比喻

の目立つことが多かった。しかしひび制れ破壊の因果関係に関する 基礎的、理諭的解析は、図一 12 に示す一婵の熱力学解析に使用さ れた供試体の解析により解答を得るとともに、製品1個の部材の最大 寸法を900mm $\times 900 \mathrm{~mm}$ として問題を解決した。

(2)その他の層間変位問題

摩擦によるロッキングを防止するため縦長に施エすることは等じ 横長の施エにして、パネルー個の層間変位を小さくし、金具の鋼鈑 厚さは1.6mにとして、層間変位を吸収し、予想外の荷重による金具 の変形を防いだ。

(3)施工例による検証

日本海中部地霞を受けた秋田県角館の施工例、阪神・淡路大震災 を受けた神戸地区での施工例、いずれにおいても、損傷が生じてい ないことから、これらの寸法の選択及びエ法に大きな問題が無かっ たことが予測できる。 


\section{5.まとめ}

雇い実工法の外壁材の取付工法を対象に、取付工法の完成度と力 ーテンウォールとしての構造的問題点を検討した結果以下のような 知見を得ることができた。

（1）取り付け手法のシステム化の必要性の発生経過

釘により各ポイントを固定した場合、カーテンウォールのシス テムとはいえない、しかし、小規模の建築物、製品が小型の場合、 製品を横長に取り付けた場合には、層間変位の認識の必要性は見 られず、一個の製品の寸法が大きく、職人 1 人による運搬が困難 になり始めた時点で、釘による取り付けに対する不安感と一定取 り付けシステムの必要性を持つ意見が出始めた。

(2) 構造的問題

1）取り付け部材の材料に関しては、あくまで、木造下地に、容易 に入手できる釘と取り付け金物による取り付けを維持し、構法的 には、雇い実エ法をカーテンウォールエ法に変換させる点に焦点 を絞っている。また、金具による層間変位の吸収は、材料間の目 地コーキングによる変位吸収に連携している。

2 ）金具の開発と適用により、外壁材を、同一の強度条件で、確実 に、一定の信頼性を持って、下地に固定することが可能となった。

(3)工法の完成度

工法の完成度の視点からして、規定の金具により取り付けるこ とは、取り付け条件が一定となり、完成度が上昇したといえる。 また、釷で直接下地に取り付けることを避け、取り付け金具を使 用することとし、しかも、その部材数が少なくなるようエ夫し、 最後に 1 個の金具で固定、スライド双方を実現できたことは、製 品の完成度が上がったことを意味すると考えられる。
謝辞

本研究を発表するに当たり、建築知識に揭載された作品とほほ同 じアングルからの、先生ご自身が撮影されたスライドを、東海大学 の吉田研介教授より拝借させていただき揭載させて頂きました。施 工後 20 年経過したにも関わらず、完成直後の状態を、本論に揭載 できたことに深く感謝致します。

参考文献

1）内田祥哉:建策構法,市ヶ谷出版,pp. 152 169, 1991.4

2）鈴木要: セメント系外壁材に関するエ法的問題点, 東京ブライゥッド中央 研究所研究報告, 1974 1980

3）吉田研介:デザインドキュメント/住宅編,建築知識,第233号,pp.19〜 78, 1978.3

4）鈴木要:エネルギー変換による表面自由エネルギー測定（基本概念と理 諭）一その1-セメント硬化物の破断応力に関する基䃈的物性测定,日本 建築学会構造系論文報告集,第347号,pp.9 17,1985.1

5）鈴木要:拘束されたセメント硬化物の破壊に関する熱力学的研究ーその 1 一熱力学の 2 大法則を使用しての解析, 日本建築学会構造系諭文報告集, 第400号, pp.11〜19,1989.6

6）鈴木要:拘束されたセメント硬化物の破壊に関する熱力学的研究一その 2 一熱力学解析結果から導かれる力の举動, 日本建策学会構造系諭文報告集, 第421号,pp.11 19,1991.3

（1997年 7 月10日原稿受理，1998年 2 月 20 日採用決定） 